\title{
MENINGKATKAN KOMPETENSI GURU DALAM PENYUSUNAN RPP DI SD NEGERI 43 AMPENAN SEMESTER DUA TAHUN PELAJARAN 2017/2018 MELALUI PENDAMPINGAN BERBASIS KKG
}

\author{
Hj. St. Nurhasnah \\ Kepala SD Negeri 43 Ampenan.
}

\begin{abstract}
Abstrak. Latar belakang diadakannya Penelitian ini adalah rendahnya kompetensi guru sasaran Di SD Negeri 43 Ampenan dalam penyusunan Rencana Pelakssanaan Pembelajaran (RPP) Berdasarkan KTSP yang berdampak kurang percaya diri dalam proses pembelajaran. Solusinya diadakan pendampingan baik secara kelompok maupun individu dalam penyusunan RPP berdasarkan KTSP. Tujuannya adalah untuk mengetahui efektifitas pelaksanaan pendampingan berbasis KKG dalam upaya meningkatkan kompetensi guru dalam menyusun RPP berdasarkan KTSP, yang bermanfaat untuk meningkatkan profesionalisme sebagai kepala sekolah dan bagi guru untuk meningkatkan proses pembelajaran di kelas. Hipotesis tindakan: meningkatkan kompetensi guru guru sasaran SD Negeri 43 Ampenan semester dua tahun pelajaran 2017/2018 dalam menyusun RPP berdasarkan KTSP. Penelitian ini dilaksanakan sebanyak dua siklus, masing-masing siklus dua kali pertemuan. Tahapan setiap siklus adalah perencanaan, pelaksanaan, pengamatan, dan refleksi. Indikator keberhasilan dalam penelitian ini adalah; 1) hasil observasi Kepala Sekolah maupun observasi guru selama proses pendampingan telah memperoleh skor rata-rata $\geq 4,0,2$ ) hasil kerja guru dalam penyusunan RPP mencapai $\geq 85 \%$ dengan nilai rata-rata $\geq 80,00$. Hasil penelitian pada siklus I observasi Kepala Sekolah rata-rata $(3,20)$, observasi guru rata-rata $(3,50)$ dan hasil kerja individual rata-rata nilai $(67,94)$ dengan prosentase ketercapaian $(0 \%)$. Pada siklus II observasi Kepala Sekolah rata-rata $(4,50)$, observasi guru rata-rata $(4,67)$ dan hasil kerja individual rata-rata nilai $(89,84)$ dengan prosentase ketercapaian $(100 \%)$. Indikator keberhasilan telah tercapai, penelitian di nyatakan berhasil dan dihentikan pada siklus II.
\end{abstract}

Kata Kunci : Pendampingan - RPP

\section{PENDAHULUAN}

Seorang kepala sekolah yang memliki dimensi kompetensi kepribadian sebagaimana disyaratkan dalam 6 (enam) kompetensi maka dijamin tidak akan ada korupsi dan kecurangan dalam penyelenggaraan pendidikan. Sebaliknya bila etos kerja kepala sekolah rendah, maka akan terjadi penurunan mutu pendidikan baik mutuguru maupun mutu peserta didik yang mengarah akan terjadinya kehancuran bertahap dalam proses menjalankan visi dan misi pendidikan di sekolah binaannya. Kompetensi kepribadian dapat diukur melalui psikotes, khususnya jiwa kepemimpinan dan diketahui sejauh mana seorang kepala sekolah memiliki jiwa kepemimpinan atau tidak. Sealain ini kemampuan menghadapi masalah dapat diukur dengan "inventori pengukuran konflik" yang terjadi di sekolah baik secara internal maupun eksternal.
Kompetensi kepala sekolah yang sangat erat dengan perkembangan etos kerja guru adalah kompetensi supervisi. Selama ini kegiatan supervisi oleh kepala sekolah kepada guru bersifat monoton dan statis, sebab kepala sekolah melakukan supervisi jika: 1) dibutuhkan untuk mengisi penilaian kinerja guru yang masuk pada SKP (Sasaran Kinerja Pegawai Negeri Sipil), 2) supervisi guru menyusun perangkat pembelajaran, 3) dalam proses pembelajaran dalam rangka mengisi blanko supervisi, selesai supervisi selesai juga kegiatannya tanpa adanya refleksi, upaya perbaikan, dan menindaklanjuti dengan kegiatan nyata seperti diadakan diklat, workshop, seminar, dll, sehingga terkesan kegiatan supervisi hanya sebagai lambang saja tanpa melihat dampak yang akan terjadi dalam upaya peningkatan mutu pendidikan di sekolah binaannya. 
Kondisi nyata yang terjadi di SD Negeri 43 Ampenan khususnya dalam proses supervisi tentang perangkat pembelajaran yang difokuskan pada penyusunan Rencana Pelaksanaan Pembelajaran (RPP) telah dilakukan pemantauan dan identifikasi terhadap RPP yang dibuat oleh 6 (enam) guru kelas I, II, III, IV, V, dan VI.

Adapun faktor penyebab rendahnya kompetensi guru SD Negeri 43 Ampenan dalam penyusunan RPP antara lain : 1) guru belum pernah mendapatkan bimbingan secara khusus bagaimana menyusun RPP Berdasarkan KTSP oleh kepala sekolah, 2) guru belum pernah mengikuti pendidikan dan pelatihan (Diklat) khusus penyusunan RPP, 3) kegiatan KKG (Kelompok Kerja Guru) di SD Negeri 43 Ampenan belum dioptimalkan, yang terjadi selama ini KKG hanya forum guru kelas bertemu, bercanda, bergurau, dan makan-makan tidak pernah serius dalam melakukan kegiatan, 4) kepedulian guru dalam menyusun RPP berdasarkan KTSP masih rendah, 5) guru masih cuek akan keberadaan RPP yang penting ngajar dari pagi sampai siang dengan apapun metode sesuai dengan kesenangan guru itu sendiri.

Banyak solusi yang bisa dilakukan oleh kepala sekolahdalam upaya meningkatkan kompetensi guru kelas SD Negeri 43 Ampenan dalam penyusunan RPP berdasarkan KTSP (kurikulum 2006). Diantaranya yang dilakukan oleh kepala SD Negeri 43 Ampenan selaku peneliti adalah diadakan pendampingan melalui kegiatan KKG bagi guru SD Negeri 43 Ampenan dalam penyusunan RPP (Rencana Pelaksanaan Pembelajaran). Beberap kelebihan pendampingan melalui kegiatan KKG antara lain: 1) melatih keberanian bagi guru SD Negeri 43 Ampenan untuk berfikir yang demokratis, objektif dan praktis, 2) bentuk hubungan antar personal antara guru yang lebih berpengalaman dengan guru yang memerlukan bimbingan khusus, 3) dapat memotivasi guru guna meningkatkan kemampuan dan ketrampilan dalam merencanakan, melaksanakan, dan membuat evaluasi terhadap RPP yang disusunnya, 4) untuk membantu guru memperoleh informasi tentang tata cara penyusunan RPP berdasarkan KTSP, dan 5) untuk saling berbagi informasi dan pengalaman dari hasil berinteraksi antar guru dalam forum KKG khususnya tentang penyusunan RPP berdasarkan KTSP.

Untuk membuktikan bahwa pelaksanaan pendampingan berbasis $\mathrm{KKG}$ dapat meningkatkan kompetensi guru SD Negeri 43 Ampenan perlu diadakannya Penelitian Tindakan Sekolah (PTS)dengan judul Meningkatkan Kompetensi Guru Dalam Penyusunan RPP Di SD Negeri 43 Ampenan Semester Dua Tahun Pelajaran 2017/2018 Melalui Pendampingan Berbasis KKG.

\section{Rumusan Masalah}

Apakah pelaksanaan pendampingan berbasis $\mathrm{KKG}$ dapat meningkatkan kompetensi guru SD Negeri 43 Ampenan dalam penyusunan Rencana Pelaksanaan Pembelajaran (RPP) berdasarkan KTSP?

\section{Tujuan Penelitian}

Untuk mengetahui efektifitas pelaksanaan pendampingan berbasis KKG dalam upaya meningkatkan kompetensi guru SD Negeri 43 Ampenan dalam penyusunan RPP berdasarkan KTSP

\section{Manfaat Penelitian}

1. Bagi Kepala Sekolah

- Hasil penelitian ini sangat bermanfaat bagi kepala SD Negeri 43 Ampenan dalam melaksanakan pembinaan akademik guru kelas maupun guru bidang studi/mata pelajaran di sekolah binaannya, khususnya upaya meningkatkan kompetensi dalam penyusunan RPP berdasarkan KTSP.

- Bermanfaat untuk memenuhi syarat kenaikan pangkat/golongan ke jenjang yang lebih tinggi.

2. Bagi Guru

- Sangat bermanfaat dalam upaya meningkatkan kompetensi khususnya dalam penyusunan RPP berdasarkan KTSP, sehinggadalam proses pembelajaran semakin kondusif dan bisa mencapai hasil seperti diharapkan.

- Sangat bermanfaat dalam upayamenjadi guru yang profesional yang mampu membelajarkan peserta didik yang aktif, kreatif, efektif, dan menyenangkan. 


\section{KAJIAN PUSTAKA}

Kompetensi Guru

Kompetensi Guru Kompetensi profesional guru menurut Sudjana (2002 : 1719) dapat dikelompokkan menjadi tiga bidang yaitu pedagogik, personal dan sosial. Kompetensi pedagogik menyangkut kemampuan intelektual seperti penguasaan mata pelajaran, pengetahuan menganai cara mengajar, pengetahuan mengenai belajar dan tingkah laku individu, pegetahuan tentang bimbingan penyuluhan, pengetahuan tentang administrasi kelas, pengetahuan tentang cara menilai hasil belajar, pengetahuan tentang kemasyarakatan serta pengetahuan umum lainnya.

Kompetensi bidang personal menyangkut kesiapan dan kesediaan guru terhadap berbagai hal yang berkenaan dengan tugas dan profesinya. Misalnya sikap menghargai pekerjaannya, mencintai dan memiliki perasaan senang terhadap mata pelajaran yang dibinanya, sikap toleransi terhadap sesama teman profesinya, memiliki kemauan yang keras untuk meningkatkan hasil pekerjaannya.

Kompetensi sosial menyangkut kemampuan guru dalam berbagai ketrampilan/berperilaku, seperti ketrampilan mengajar, membimbing, menilai, menggunakan alat bantu pengajaran, bergaul atau berkomunikasi dengan siswa, ketrampilan menumbuhkan semangat belajar para siswa, ketrampilan menyusun persiapan/ perencanaan mengajar, ketrampilan melaksanakan administrasi kelas, dan lainlain. Perbedaan dengan kompetensi kognitif terletak pada sifatnya. Kompetensi kognitif berkenaan dengan aspek teori atau pengetahuannya, pada kompetensi perilaku yang diutamakan adalah praktek/ketrampilan melaksanakannya.

Berdasarkan Peraturan Pemerintah Nomor 19 Tahun 2005 tentang Standar Nasional Pendidikan, guru harus memiliki kompetensi pedagogik, kepribadian, profesional, dan sosial (Depdiknas, $2005: 24$, $90-91)$.

1. Kompetensi pedagogik merupakan kemampuan yang berkenaan dengan pemahaman peserta didik dan pengelola pembelajaran yang mendidik dan dialogis.
Secara substantif kompetensi ini mencakup kemampuan pemahaman terhadap peserta didik, perancangan dan pelaksanaan pembelajaran, evaluasi hasil belajar, dan pengembangan peserta didik untuk mengaktualisasikan berbagai potensi yang dimilikinya.

2. Kompetensi kepribadian merupakan kemampuan personal yang mencerminkan kepribadian yang yang mantap, arif, dewasa, dan berwibawa, menjadi teladan bagi peserta didik, dan berakhlak mulia.

3. Kompetensi profesional merupakan kemampuan yang berkenaan dengan penguasaan materi pembelajaran bidang studi secara luas dap mendalam yang mencakup penguasaan substansi isi materi kurikulum matapelajaran di sekolah dan substansi keilmuan yang menaungi materi kurikulum tersebut, serta menambah wawasan keilmuan sebagai guru.

4. Kompetensi sosial berkenaan dengan kemampuan pendidik sebagai bagian dari masyarakat untuk berkomunikasi dan bergaul secara efektif dengan peserta didik, sesama pendidik, tenaga kependidikan, orangtua/wali peserta didik, dan masyarakat sekitar.

Yang dimaksud dengan kompetensi guru dalam penelitian tindakan sekolah (PTS) ini adalah kemampuan 6 (enam) guru dalam penyusunan Rencana Pelaksanaan Pembelajaran (RPP) berdasarkan KTSP. Adapaun ciri-ciri RPP dikatakan baik dan benar adalah: 1) memuat aktifitas proses belajar mengajar yang akan dilaksanakan oleh guru dan menjadi pengalaman belajar bagi peserta didik, 2) langkah-langkah pembelajaran disusun secara sistematis agar tujuan pembelajaran dapat dicapai, 3) langkah-langkah pembelajaran disusun serinci mungkin, sehingga apabila RPP digandakan guru lain (misalnya, ketiga guru mata pelajaran tidak hadir) mudah dipahami dan tidak menimbulkan penafsiran ganda.

\section{Pendampingan}

Pendampingan adalah sebuah bentuk hubungan yang memungkinkan terjadinya proses berbagi keterampilan dan pengalaman baik professional, maupun personal yang mendorong proses tumbuh dan berkembang sepanjang proses yang terjadi. Pendampingan 
merupakan bentuk hubungan antar personal antara seseorang yang dipandang lebih berpengalaman atau lebih professional dan seseorang yang diposisikan masih kurang berpengalaman atau kurang professional. Proses pendampingan didasarkan pada pemberian dorongan, komentar dan saran yang bersifat membangun, terlaksana dalam suasana keterbukaan, saling percaya dan saling menghargai, serta keinginan yang kuat untuk berbagi dan belajar satu sama lain. Keseluruhan proses dan semua aspek pendampingan terjadi karena hubungan yang terjalin antara pihak yang terlibat dalam pendampingan adalah hubungan yang sudah lama terbangun.

Pada dasarnya, konsep mentoring mencakup tiga komponen, yaitu: pendamping, yang terdampingi, dan proses pendampingan. Pendamping bisa seorang guru, sponsor, konselor, penasehat, teman sejawat, pendukung, orang kepercayaan, atau model. Yang terdampingi biasanya adalah seseorang yang masih pemula dan digambarkan sebagai mitra peserta dalam proses pendampingan. Proses pendampingan adalah pengembangan hubungan antara pendamping dan yang terdampingi. Definisi pendampingan sangat beragam tergantung pada strategi yang digunakan. Secara umum, pendampingan adalah proses yang melibatkan seseorang yang lebih berpengalaman, profesional, pakar untuk memberikan dukungan, bimbingan, dan nasehat kepada, serta berbagi pengalaman dengan rekan yang kurang berpengalaman.

Dalam wujudnya yang paling efektif, pendampingan adalah kemitraan pembelajaran yang melibatkan kerjasama dan peluang untuk menghadapi tantangan dan melakukan refleksi berkelanjutan oleh kedua belah pihak yang terlibat. Hubungan pendampingan bisa juga berupa kemitraan sejawat yang di dalamnya, posisi dan peran pendamping dan yang terdampingi bisa saja bertukar berdasarkan konteks tertentu.

Yang dimaksud dengan pendampingan dalam penelitian tindakan sekolah (PTS) ini adalah kepala SD Negeri 43 Ampenan selaku peneliti membimbing/mendampingi terhadap 6 (enam) guru sasaran dalam penyusunan RPP berdasarkan KTSP. Dalam pelaksanaannya pendampingan dilakukan melalui 2 (dua) tahapan. Tahap I semua guru dikumpulkan untuk mendapatkan penjelasan teknik tata cara penyusunan RPP berdasarkan KTSP sesuai dengan bidang studi/mata pelajaran yang diampunya. Tahap II yaitu pendampingan individual, dimana peneliti mendampingi secara individu dalam kelompok kecil untuk menjelaskan lebih rinci tata cara menyusun RPP berdasarkan KTSP.

\section{Kelompok Kerja Guru (KKG)}

Trimo (2007: 12) Kelompok Kerja Guru yaitu suatu organisasi profesi guru yang bersifat struktural yang dibentuk oleh guruguru di suatu wilayah atau gugus sekolah sebagai wahana untuk saling bertukaran pengalaman guna meningkatkan kemampuan guru dan memperbaiki kualitas pembelajaran.

Menurut Buchari Zainun 1987 (dalam, Suryosubroto 2004: 1) ada lima faktor yang mendasari kegiatan manusia dalam organisasi yaitu:

a. Faktor spesialisasi dan pembagian kerja;

b. Faktor koordinasi;

c. Faktor tujuan;

d. Faktor prosedur kerja;

e. Faktor dinamika lingkungan.

Sedangkan Sumadji (2013: 1) menyatakan, "Kelompok kerja guru ini merupakan wadah atau tempat bagi guru untuk bermusyawarah tentang hal-hal untuk peningkatan mutu dalam pembelajaran".

Pedoman Pembinaan Gugus PAUD (2012: 3) menyatakan bahwa "Kelompok Kerja Guru (KKG) PAUD merupakan program kerja gugus sebagai wahana bengkel kerja guru-guru anggota Gugus".

Muhtadi (2008: 13) menyatakan, "Pembentukan KKG bertujuan untuk memfasilitasi kegiatan yang dilakukan di pusat kegiatan guru berdasarkan masalah dan kesulitan yang dihadapi guru, kemudian memberikan bantuan profesional kepada guru kelas dan mata pelajaran di sekolah, serta meningkatkan pemahaman, keilmuan, keterampilan dan pengembangan sikap profesional berdasarkan kekeluargaan dan saling mengisi (sharing)".

Direktorat Pembinaan TK dan SD, Sriwasono (2010: 2) menyatakan, "tujuan umum mengembangkan kegiatan KKG untuk meningkatkan mutu pembelajaran sesuai dengan standar pelayanan pendidikan dalam 
kerangka penjaminan mutu pendidikan nasional".

Menurut Standar Pengembangan KKG

Derektorat Profesi Pendidik Direktorat Jendral Peningkatan Mutu Pendidikan dan Tenaga Kependidikan Departemen Pendidikan dan Kebudayaan Republik Indonesia, tujuan KKG adalah:

a. Memperluas wawasan dan pengetahuan guru dalam berbagai hal, khususnya penguasaan substansi materi pembelajaran, penyusunan silabus, penyusunan bahan-bahan pembelajaran, strategi pembelajaran, metode pembelajaran, memaksimalkan pemakaian sarana/prasarana belajar, memanfaatkan sumber belajar, dsb

b. Memberikan kesempatan kepada anggota kelompok kerja atau musyawarah kerja untuk berbagi pengalaman serta saling memberikan bantuan dan umpan balik;

c. Meningkatkan pengetahuan dan keterampilan, serta mengadopsi pendekatan pembaharuan dalam pembelajaran yang lebih profesional bagi peserta kelompok kerja atau musyawarah kerja;

d. Memberdayaan dan membantu anggota kelompok kerja dalam melaksanakan tugas-tugas pembelajaran di sekolah;

e. Mengubah budaya kerja anggota kelompok kerja atau musyawarah kerja (meningkatkan pengetahuan, kompetensi dan kinerja) dan mengembangkan profesionalisme guru melalui kegiatankegiatan pengembangan profesionalisme di tingkat KKG;

f. Meningkatkan mutu proses pendidikan dan pembelajaran yang tercermin dari peningkatan hasil belajar peserta didik;

g. Meningkatkan kompetensi guru melalui kegiatan-kegiatan di tingkat KKG.

Yang dimaksud dengan kelompok kerja guru (KKG) dalam penelitian ini adalah 6 (enam) guru SD Negeri32 Mataram yang menjadi sasaran dalam pelaksanaan pendampingan dalam penyusunan RPP berdasarkan Kurikulum 2006 (KTSP). Kegiatan nyata KKG SD Negeri 43 Ampenan yaitu penysunan Rencana Pelaksanaan Pembelajaran (RPP) yang dibimbing langsung oleh kepala sekolah selaku peneliti. Dalam kegiatan ini semua guru kelas dari kelas I sampai dengan guru kelas VI menyusun RPP secara individualdalam forum KKG. Kendala/kesulitan yang dialami oleh guru langsung diberikan bimbingan, perbaikan, dan penyempurnaansesuai dengan situasi dan kondisi pada saat KKG yang diselenggarakan di SD Negeri 43 Ampenan.

\section{Rencana Pelaksanaan Pendampingan (RPP)}

Pada hakekatnya penyusunan RPP bertujuan merancang pengalaman belajar siswa untuk mencapai tujuan pembelajaran. Tidak ada alur pikir (algoritma) yang spesifik untuk menyusun suatu RPP, karena rancangan tersebut seharusnya kaya akan inovasi sesuai dengan spesifikasi materi ajar dan lingkungan belajar siswa (sumber daya alam dan budaya lokal, kebutuhan masyarakat serta perkembangan ilmu pengetahuan dan teknologi). Pengalaman dari penilaian portofolio sertifikasi guru ditemukan, bahwa pada umumnya RPP guru cenderung bersifat rutinitas dan kering akan inovasi. Mengapa? diduga dalam melakukan penyusunan RPP guru tidak melakukan penghayatan terhadap jiwa profesi pendidik. Keadaan ini dapat dipahami karena, guru terbiasa menerima borang-borang dalam bentuk format yang mengekang guru untuk berinovasi dan penyiapan RPP cenderung bersifat formalitas. Bukan menjadi komponen utama untuk sebagai acuan kegiatan pembelajaran. Sehingga ketika otonomi pendidikan dilayangkan tak seorang gurupun bisa mempercayainya. Buktinya perilaku menyusun RPP dan perilaku mengajar guru tidak berubah jauh.

Acuan alur pikir yang dapat digunakan sebagai alternatif adalah:

1. Kompetensi apa yang akan dicapai.

2. Indikator-indikator yang dapat menunjukkan hasil belajar dalam bentuk perilaku yang menggambarkan pencapaian kompetensi dasar.

3. Tujuan pembelajaran yang merupakan bentuk perilaku terukur dari setiap indikator.

4. Materi dan uraian materi yang sesuai dengan kebutuhan belajar siswa agar ianya dapat mencapai tujuan pembelajaran. 
5. Metode-metode yang akan digunakan dalam pembelajaran.

6. Langkah-langkah penerapan metodemetode yang dipilih dalam satu kemasan pengalaman belajar.

7. Sumber dan media belajar yang terkait dengan aktivitas pengalaman belajar siswa.

8. Penilaian yang sesuai untuk mengukur ketercapaian tujuan pembelajaran.

Secara umum, ciri-ciri Rencana Pelaksanaan Pembelajaran (RPP) yang baik adalah sebagai berikut:

1. Memuat aktivitas proses belajar mengajar yang akan dilaksanakan oleh guru yang akan menjadi pengalaman belajar bagi siswa.

2. Langkah-langkah pembelajaran disusun secara sistematis agar tujuan pembelajaran dapat dicapai.

3. Langkah-langkah pembelajaran disusun serinci mungkin, sehingga apabila RPP digunakan oleh guru lain (misalnya, ketiga guru mata pelajaran tidak hadir), mudah dipahami dan tidak menimbulkan penafsiran ganda.

\section{Kerangka Konseptual}

Variabel harapan dalam penilaian ini adalah meningkatnya kompetensi 6 (enam) guru sasaran dalam penyusunan RPP berdasarkan KTSP, sedangkan variabel tindakan dalam penelitian iniadalah melaksanakan pendampingan secara klasikal (kelompok besar) dan pendampingan individual (kelompok kecil/perorangan) berbasis Kelompok Kerja Guru (KKG).

\section{Hipotesis Tindakan}

jika pendampingan berbasis KKG dilaksanakan dengan baik, maka kompetensi guru dalam penyusunan RPP berdasarkan KTSP di SD Negeri 43 Ampenan semester dua Tahun Pelajaran 2017/2018 dapat di tingkatkan.

\section{PROSEDUR PENELITIAN}

Penelitian Tindakan Sekolah (PTS) ini dilaksanakan di SD Negeri 43 Ampenan yang pelaksanaannya melalui kegiatan pendampingan berbasis KKG bagi 6 (enam) guru sasaran dalam penyusunan RPP Berdasarkan KTSP yang dilaksanakan dalam forum KKG sekolah.
Jenis Tindakan dan Dampak yang diharapkan

- Jenis Tindakan:

Pendampingan berbasis KKG dalam penyusunan RPP Berdasarkan KTSP bagi 6 (enam) guru sasaran di SD Negeri 43 Ampenan semester dua Tahun Pelajaran 2017/2018

- Dampak yang diharapkan:

Meningkatnya kompetensi 6 (enam) guru sasaran dalam penyusunan RPP Berdasarkan KTSP.

\section{Perencanaan Tindakan}

\section{Jenis tindakan yang dilakukan}

Untuk mendapatkan gambaran riil tentang skenario pelaksanaan tindakan pada kegiatan pendampingan berbasis $\mathrm{KKG}$ ini dapat di gambarkan sebagai berikut:

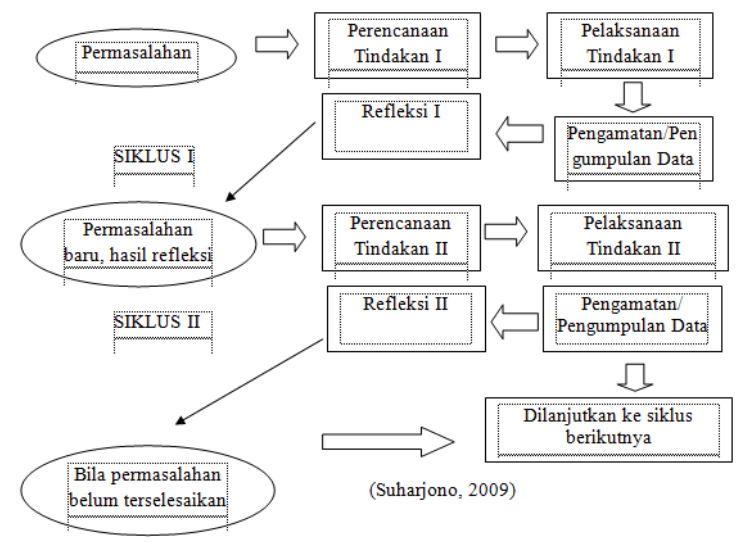

\section{Pelaksanaan Tindakan}

Dalam kegiatan ini peneliti melakukan kegiatan pendampingan penyusunan Rencana Pelaksanaan Pembelajaran (RPP) berdasarkan KTSP dengan berpedoman pada perencanaan pendampingan yang telah di tetapkan. Adapun jenis instrumen yang digunakan dalam penelitian ini sebagai berikut:

1. Instrumen pengamatan/observasi kepala sekolah dilakukan oleh observer (pengawas selaku pembimbing)

2. Instrumen pengamatan/observasi guru peserta pendampingan dilakukan oleh peneliti (kepala sekolah)

3. Instrumen penilaian hasil kerja individual dalam penyusunan RPP Berdasarkan KTSP dilakukan oleh peneliti, ini sekaligus merupakan tolak ukur berhasil tidaknya dalam penyusunan RPP melalui pendampingan berbasis KKG sesuai dengan indikator keberhasilan yang telah di tetapkan. 


\section{Evaluasi dan Refleksi Tindakan}

Pada tahapan ini peneliti melakukan kajian dan penelitian proses tindakan dan hasil atau dampak tindakan terhadap perubahan perilaku sasaran (nana Sujana, 2009:39). Adapun kegiatan riilnya adalah: 1) membandingkan hasil pengamatan pelaksanaan kerja kelompok/diskusi yang difokuskan kegiatan penyusunan RPP Berdasarkan KTSP, 2) membandingkan hasil kerja individual dari 6 (enam) guru sasaran dalam penyusunan RPP dengan indikator keberhasilan yang telah ditetapkan.

\section{Siklus Tindakan}

Dalam penelitian ini di rencanakan sebanyak 2 (duaa) siklus, masing-masing siklus 1 (satu) kali pertemuan dengan agenda 2 (dua) kegiatan secara terpadu yaitu pendampingan klasikal/kelompok besar dan pendampingan individual/kelompok kecil. Kegiatan masing-masing siklus terdiri dari 4 (empat) tahapan yaitu perencanaan, pelaksanaan, observasi, dan refleksi. Untuk mendapatkan gambaran secara rinci kegiatan masing-masing tahapan dapat di jelaskan sebagai berikut:

\section{SIKLUS I}

\section{Tahap I : Perencanaan Tindakan}

1.1. Menyusun materi pendampingan

1.2. Menetapkan scenario dan langkahlangkah pendampingan yang tertuang dalam Rencana Pelaksanaan pendampingan (RPP)

1.3. Menyusun instrument observasi kepala sekolah dan observasi guru

1.4. Menentukan jadwal kegiatan pendampingan

1.5. Menyusun pedoman analisa data hasil observasi dan tugas individu.

\section{Tahap II. Pelaksanaan Tindakan}

Pada kegiatan pendampingan secara berkelompok yang kegiatannya adalah :

2.1. Menyampaikan materi tentang tata cara penyusunan RPP Berdasarkan KTSP.

2.2. Melaksanakan diskusi kelompok kecil dalam penyusunan RPP.

2.3. Memberikan bimbingan secara berkelompok/perorangan.

2.4. Memberikan solusi terhadap permasalahan yang dihadapi oleh guru

2.5. Memberikan penguatan/reward

2.6. Memberikan tugas individual.
Pada kegiatan pendampingan individual yang dilakukan secara bergiliran, dengan cara peneliti mendekati guru satu persatu dalam kelompok untuk membimbing secara individual agar permasalahanppermasalahan dapat dipecahkan dengan baik dan benar.

Tahap III. Observasi/pengumpulan Data

3.1. Pengamatan terhadap aktifitas guru peserta pendampingan

3.2. Pengamatan terhadap kinerja guru dalam penyusunan RPP Berdasarkan KTSP.

3.3. Menilai hasil kerja guru secara individual

Tahap IV. Refleksi

4.1. Renungan atas data hasil observasi dan hasil kerja secara individual.

4.2. Pengolahan data hasil penelitian dan mencocokkan dengan indikator keberhasilan.

4.3. Rencana perbaikan dan penyempurnaan

4.4. Memberikan penguatan atas hasil yang diperolehnya.

4.5. Rencana tindak lanjut.

\section{SIKLUS II}

Jenis kegiatan pada siklus II ini pada dasarnya sama dengan siklus I, bedanya hanya terjadi perbaikan/penyempurnaan dalam pelaksanaannya.

\section{Indikator Keberhasilan}

1. Hasil observasi kepala sekolah maupun observasi guru peserta pendampingan telah mencapai skor rata-rata $\geq 4,0$ (Kategori baik).

2. Hasil kerja secara individual penyusunan RPP Berdasarkan KTSP dinyatakan telah berhasil jika mencapai $\geq 85 \%$ dengan nilai rata-rata $\geq 80,00$ (Kategori Baik).

\section{LAPORAN HASIL DAN PEMBAHASAN Tahap Perencanaan}

Pada tahapan ini peneliti melakukan: 1) menyusun materi pendampingan, 2) menetapkan skenario dan langkah-langkah pendampingan yang tertuang dalam Rencana Pelaksanaan Pendampingan (RPP), 3) menyusun instrumen observasi kepala sekolah dan instrumen observasi guru, 4) menentukan jadwal kegiatan pendampingan, 5) menyusun pedoman analisis data 


\section{Tahap Pelaksanaan}

Pada tahapan ini peneliti melakukan pendampingan secara klasikal maupun pendampingan secara individual, dengan rincian kegiatan sebagai berikut:

- Pendampingan klasikal/kelompok; 1) menyampaikan materi tentang tata cara penyusunan RPP Berdasarkan KTSP, 2) melaksanakan diskusi kelompok kecil dalam penyusunan RPP, 3) memberikan bimbingan secara berkelompok, 4) memberikan solusi terhadap permasalahan yang dihadapi oleh guru, 5) memberikan penguatan/reward, dan 6) memberikan tugas individual.

- Pendampingan individual, jenis kegiatannya adalah; 1) pada saat guru bekerja dalam kelompok/diskusi kelompok peneliti membimbing guru yang mengalami kesulitan dalam penyusunan RPP secara kelompok kecil/perorangan, 2) memberikan solusi/pemecahan terhadap kesulitan yang dirasakan secara individual, 3) kegiatan seterusnya sampai ke 6 (enam) guru peserta pendampingan mendapatkan giliran pendampingan secara individual

\section{Tahap Observasi}

Observasi Kepala Sekolah Memperoleh skor rata-rata sebesar 3,20, Observasi guru Memperoleh skor rata-rata sebesar 3,50, dan Nilai Individual hasil penyusunan RPP Berdasarkan KTSP Memperoleh nilai rata-rata sebesar 67,94

\section{Tahap Refleksi}

Pada tahapan ini peneliti merenung atas perolehan data hasil observasi kepala sekolah, observasi guru, dan nilai individual hasil penyusunan RPP Berdasarkan KTSP. Selanjutnya peneliti mengolah data dan hasilnya di cocokkan dengan indikator keberhasilan.

Karena perolehan hasil masih dibawah indikator keberhasilan yang direncanakan, maka pada siklus berikutnya akan diadakan perbaikan dan penyempurnaan dari serangkaian kegiatan pendampingan secara klasikal maupun secara individual, namun demikian peneliti tetap memberikan penguatan atas hasil yang diperolehnya dan penelitian dilanjutkan pada siklus II dengan mengoptimalkan semua jenis tindakan dalam pendampingan sehingga di peroleh hasil yang memuaskan.

\section{Deskripsi Siklus II}

Tahapan perencanaan pada siklus II jenis kegiatannya masih sama dengan siklus I, bedanya pada siklus II ini lebih memfokuskan perbaikan/penyempurnaan dalam proses pendampingan klasikal maupun pendampingan individual, yang jenis kegiatannya adalah: 1) menyempurnakan materi pendampingan, 2) menetapkan skenario pendampingan, 3) menetapkan instrumen observasi kepala sekolah maupun observasi guru, 4) menetapkan jadwal kegiatan pendampingan, 5) menyusun pedoman analisis data hasil observasi dan tugaas individu

\section{Tahap Pelaksanaan}

an

Pendamping klasikal/kelompok;

1)menyampaikan/merefleksi hasil perolehan data pada siklus I, 2) menjelaskan ulang tata cara penyusunan RPP Berdasarkan KTSP secara lebih rinci, 3) perbaikan RPP secara berkelompok/diskusi kelompok, 4) memberikan refleksi terhadap hasil kerja kelompok yang mengalami kendala, 5) memberikan penghargaan/reward dan 6) memberikan tugas individual.

Pendamping an individual/kelompok kecil; 1) pada saat proses kerjasama dalam kelompok, peneliti mengamati/mencermati hasil kerja secara individual, 2) memberikan bimbingan/merefleksi terhadap hasil kerja individual yang masih mengalami kendala, 3) begitu seterusnya sampai semua guru peserta pendampingan mendapatkan pendampingan secara individual.

\section{Tahap Observasi/Pengumpulan Data}

Observasi Kepala Sekolah

Memperoleh skor rata-rata sebesar 4,50, Observasi guru Memperoleh skor rata-rata sebesar 4,67, dan Nilai Individual hasil penyusunan RPP Berdasarkan KTSP Memperoleh nilai rata-rata sebesar 89,84.

\section{Tahap Refleksi}

Pada tahapan ini peneliti merenung atas perolehan data hasil observasi kepala sekolah, observasi guru, dan nilai individual hasil penyusunan RPP Berdasarkan KTSP. 
Kemudian di olah engan menggunakan rumus yang telah ditetapkan. Hasil perolehan data di cocokkan dengan indikator keberhasilan.

Karena perolehan hasil siklus II sudah melebihi indikator keberhasilan, maka tidak perlu ada perbaikan/penyempurnaan dalam penyusunan RPP Berdasarkan KTSP, selanjutnya peneliti memberikan penghargaan/reward kepada semua guru peserta pendampingan karena dari 6 (enam) guru sasaran $100 \%$ sudah memperoleh nilai rata-rata $\geq 80,00$. Penelitian dinayatakan berhasil dan tindakan dihentikan pada siklus II.

\section{HASIL DAN PEMBAHASAN SIKLUS I}

Dalam penyusunan materi pendampingan, menetapkan skenario dan langkah-langkah pendampingan, dan perencanaan penyusunan instrumen observasi kepala sekolah dan instrumen observasi guru peneliti mengalami beberapa kendala yaitu dalam pendampingan klasikal maupun pendampingan individual. Faktor penyebabnya adalah karena peneliti masih belum menemukan strategi yang tepat dan diterima oleh peserta. Solusi yang dilakukan oleh peneliti adalah dengan meminta petunjuk dari pengawas pembimbing, sekolah diberikan petunjuk dan arahan nyata maka pendampingan klasikal dan individualpun terlaksana dengan baik.

\section{Tahap Pelaksanaan}

Kegiatan nyata dalam pelaksanaan pendampingan dapat dijabarkan sebagai berikut: pada saat menyampaikan materi tentang tata cara penyusunan RPP berdasarkan KTSP mengalami kendala yang disebabkan peneliti masih kekurangan sumber/buku literatur, sehingga berdampak tertundanya dalam penyusunan, solusi yang dilakukan peneliti mencari beberapa buku literatur terkait dengan tata cara penyusunan RPP termasuk mencari di internet, akhirnya materi pendampingan dapat tersusun dengan baik.

Dalam pelaksanaan bimbingan pada saat peserta pendampingan melakukan diskusi/kerjasama dalam kelompok, peneliti berkeliling memberikan bimbingan dan solusi terhadap peserta yang mengalami kesulitan. Pada kegiatan ini peneliti tidak mengalami hambatan/permasalahan artinya berjalan sesuai dengan rencana.

\section{Tahap Observasi/Pengumpulan Data}

Hasil perolehan skor selama pendampingan pada siklus I peneliti memperoleh skor rata-rata $(3,20)$ dari indikator keberhasilan yang direncanakan yaitu $\geq 4,0$, Perolehan skor rata-rata aktifitas peserta pendampingan pada siklus I yaitu $(3,50)$ dari indikator keberhasilan $(\geq 4,0)$. Perolehan nilai rata-rata hasil kerja guru dalam penyusunan RPP berdasarkan KTSP secara individual memperoleh rata-rata $(67,94)$ dari indikator keberhasilan $\geq 80,0$ (kategori baik). Dari 6 (enam) guru peserta pendampingan pada siklus I belum ada satu guru pun yang dinyatakan memperoleh nilai rata-rata $\geq 80,00$. Ini artinya pada siklus I presentasi pencapaian hasil kerja individual masih $0 \%$, dalam arti belum ada yang tuntas sesuai indikator yang telah ditetapkan. Pada kegiatan siklus berikutnya peneliti harus mampu memotivasi peserta pendampingan dalam upaya mencapai indikator keberhasilan sebagai dampak nyata dari hasil pendampingan.

\section{Tahap Refleksi}

Perolehan skor rata-rata hasil observasi kepala sekolah selama proses pendampingan baru memperoleh skor ratarata $(3,20)$, sementara perolehan hasil observasi peserta pendampingan sebagai aktifitas peserta selama pendampingan baru memperoleh skor rata-rata $(3,50)$, dan nilai rata-rata hasil penyusunan RPP berdasarkan KTSP baru mencapai nilai rata-rata $(67,94)$. Dari perolehan hasil dimaksud peneliti merenung mencari faktor kendala dan penyebab sehingga hasil masil belum optimal. Dari hasil renungan itu akhirnya peneliti menemukan solusi untuk dapat dilaksanakan pada kegiatan pendampingan siklus berikutnya.

\section{SIKLUS II}

\section{Tahap Perencanaan}

Kesalahan-kesalahan yang terjadi pada siklus I sudah diperbaiki pada siklus II, sehingga pada tahapan ini peneliti bisa melakukan dengan baik. Kegiatan pada tahap perencanaan ini meliputi; 1) penyempurnaan penyusunan materi pendampingan, 2) perbaikan skenario/strategi/langkah-langkah 
pendampingan yang mengarah kepada peserta aktif, 3) menetapkan instrumen observasi kepala sekolah dan instrumen observasi guru, 4) menentukan jadwal kegiatan dan menetapkan pedoman analisa data hasil observasi dan hasil kerja individual.

\section{Tahap Pelaksanaan}

Pada tahapan ini, peneliti terlebih dahulu melakukan refleksi atas capaian hasil yang diperoleh pada siklus I. Kendala-kendala dan permasalahan yang terjadi dibahas sampai semua peserta pendampingan memahami dan menyadari akan kekurangan, kesalahan dan hal-hal yang bersifat krusial dapat dipecahkan pada saat kegiatan refleksi.

Kegiatan selanjutnya peneliti menyampaikan materi pendampingan secara perlahan-lahan, ringkas dan jelas sehingga peserta pendampingan lebih paham dan mengerti tata cara penyusunan RPP berdasarkan KTSP.

\section{Tahap Observasi}

Pada siklus II perolehan skor rata-rata hasil observasi kepala sekolah adalah $(4,50)$ dari indikator keberhasilan $\geq 4,00$, ini artinya menunjukkan peningkatan yang sangat signifikan bila dibandingkan dengan perolehan hasil pada siklus I. Skor rata-rata hasil observasi guru yaitu aktifitas selama pendampingan dalam forum KKG memperoleh skor rata-rata $(4,67)$ dari indikator keberhasilan $\geq 4,00$. Dari hasil ini nampak nyata bahwa aktifitas peserta pendampingan pada siklus II mengalami peningkatan yang sangat tajam karena sudah mampu melampaui indikator keberhasilan yang telah ditetapkan. Nilai rata-rata hasil kerja individual dalam penyusunan RPP berdasarkan KTSP yakni $(89,84)$ dari indikator keberhasilan $(\geq 80,00)$.

\section{Tahap Refleksi}

Berdasarkan hasil akhir perolehan skor rata-rata observasi kepala sekolah dan observasi guru serta hasil kerja individual penyusunan RPP berdasarkan KTSP semuanya telah melampaui indikator keberhasilan maka dapat disimpulkan bahwa: 1) upaya untuk menyempurnakan materi pendampingan dinyatakan berhasil, 2) pelaksanaan untuk memperbaiki strategi penyampaian materi tata cara penyusunan RPP dan strategi pendampingan telah mampu meningkatkan motivasi dan kinerja guru sehingga perolehan hasil yang diharapkan dapat tercapai, 3) upaya untuk mengoptimalkan pelaksanaan pendampingan individual telah membawa dampak positif terhadap perolehan hasil dalam penyusunan RPP berdasarkan KTSP.

Karena semua indikator keberhasilan telah tercapai maka penelitian tindakan sekolah dihentikan pada siklus II dan dinyatakan berhasil memotivasi guru untuk lebih bergairah dan lebih bersemangat dalam upaya penyusunan RPP berdasarkan KTSP. Penelitian Tindakan Sekolah dengan judul "Meningkatkan Kompetensi Guru Dalam Penyusunan RPP Di SD Negeri 43 Ampenan Semester Dua Tahun Pelajaran 2017/2018 Melalui Pendampingan Berbasis KKG", dinyatakan "BERHASIL"

\section{KESIMPULAN DAN SARAN \\ Kesimpulan}

Perolehan data selama penelitian dapat dipaparkan sebagai berikut:

\begin{tabular}{|c|c|c|c|c|c|}
\hline \multirow[b]{2}{*}{ No } & \multirow[b]{2}{*}{ Jenis Keggiatan } & \multirow{2}{*}{$\begin{array}{c}\text { Indikator' } \\
\text { Keberhasilan }\end{array}$} & \multicolumn{2}{|c|}{ Perolehan } & \multirow[b]{2}{*}{ Ket } \\
\hline & & & $\begin{array}{c}\text { Siklus } \\
\text { I }\end{array}$ & $\begin{array}{c}\text { Siklus } \\
\text { II }\end{array}$ & \\
\hline 1. & Hasil Observasi Kepala Sekolah & $\geq 4,00$ & 3,20 & 4,50 & Meningkat \\
\hline 2. & Hasil Observasi Gunu & 24,00 & 3,50 & 4,67 & Meningkat \\
\hline 3. & Hasil Kerja Individual & 280,00 & 67,94 & 89,84 & \\
\hline
\end{tabular}

Pelaksanaan pendampingan berbasis MGMP sangat efektif untuk meningkatkan kompetensi guru dalam penyusunan RPP berdasarkan KTSP bagi guru sasaran 6 (enam) guru SD Negeri 43 Ampenan dalam penyusunan RPP berdasarkan KTSP. Hal ini dibuktikan meningkatnya perolehan hasil observasi dan hasil kerja individual dari siklus I ke siklus II. Penelitian tindakan sekolah (PTS) ini dinyatakan berhasil dan dihentikan pada siklus II.

Saran

Disarankan kepada rekan kepala sekolah lain untuk melakukan pendampingan dengan semua guru mata pelajaran dibawah binaan pada sekolah masing-masing dalam upaya meningkatkan kompetensinya khususnya dalam penyusunan RPP berdasarkan KTSP yang bisa diterapkan dalam proses pembelajaran di kelas senyatanya. Dampak yang diharapkan yaitu meningkatnya kualitas/mutu peserta didik di 
sekolah binaan melalui proses pembelajaran yang dilandasi dengan penyusunan RPP berdasarkan KTSP.

Kepada seluruh guru SD Negeri 43 Ampenan disarankan untuk membiasakan melakukan musyawarah bersama dalam forum KKG mata pelajaran yang diampunya, khususnya dalam penyusunan RPP berdasarkan KTSP, sehingga berdampak meningkatnya kompetensi guru dalam proses pembelajaran di kelas senyatanya dan pada gilirannya prestasi belajar peserta didik dapat ditingkatkan.

\section{DAFTAR PUSTAKA}

Anonim, 2018, pengertian-tujuan-danmanfaat-kkg, dalam http://posnanggroe.com/2015/11/11/pe ngertian-tujuan-dan-manfaat-kkg/, diakses tanggal 7 Januari 2018, pukul 15.45 Wita

Anonim, 2018, Definisi Pendampingan, dalam

https://kamuspsikososial.wordpress.co $\mathrm{m} /$ tag/definisi-pendampingan/, diakses tanggal 10 Januari 2018 Pukul 13.40 Wita

Anonim, 2018, Pengertian Pendampingan, dalam http://www.bintans.web.id/2010/12/pengertianpendampingan.html, diakses tanggal 10 Januari 2018 Pukul 13.40 Wita

Anonim, 2018, Kompetensi Guru, dalam https://karyono1993.wordpress.com/th esis/kompetensi-guru/, diakses tanggal 11 Januari 2018 Pukul 11.00 wita

Anonim, 2018, Pengertian Kompetensi dan Kompetensi Guru, dalam https://mujibjee.wordpress.com/2010/ 01/11/pengertian-kompetensi-dankompetensi-guru/, di akses 15 Januari 2018 Pukul 12.45 wita

Anonim, 2018, mgmp-musyawarah-gurumatapelajaran, dalam http://melshandyohayo.blogspot.com/2012/06/mgmpmusyawarah-gurumatapelajaran.html, diakses Tanggal 15 Januari 2018 Pukul 16.50 Wita.
Anonim, 2018, Memberdayakan MGMP, dalam

http://edukasi.kompasiana.com/2012/0 5/15/memberdayakan-mgmp/, diakses 15 Januari 2017 Pukul 16.50 Wita

Irwan sahaja , 2018, Pengertian Kelompok Kerja Guru, dalam http://irwansahaja.blogspot.co.id/2014 108/pengertian-kelompok-kerja-gurukkg.html, diakses tanggal 8 Januari 2017, pukul 12.30 Wita

Kementrian Pendidikan Nasional, 2010, Kepemimpinan Pembelajaran, Dirjen PMPTK

Keputusan Mentri Pendidikan Nasional No. 16 Tahun 2007, Standar Kualifikasi Akademik dan Kompetensi Guru.

Nana Sujana, 2009, Pendidikan Tingkat KePenelitian Konsep Dan Aplikasinya Bagi Peneliti Sekolah, Jakarta: LPP Bina Mitra.

Purnadi Pungki, M.W., 2009, KompetensiFaktor Kunci Keberhasilan, dalam http://vibizconsulting.com. Diakses tanggal 11 Agustus 2015 pukul 19.35 wita

Peraturan Pemerintah No. 19 tahun 2005 tentang Standar Nasional Pendidikan

Suharjono, 2009, Melaksanakan Sekolah Sebagai Kegiatan Penelitian Tindakan Sekolah Sebagai Kegiatan Pengembangan Profesi Penelitia Sekolah, Jakarta: Bumi Aksara.

Suharjono, 2012, Publikasi Ilmiah Dalam Kegiatan Pengembangan Keprofesian Berkelanjutan Bagi Guru, Jakarta: Cakrawala Indonesia.

Undang-Undang Republik Indonesia, No. 14 Tahun 2005 , Guru dan Dosen Daftar Pustaka

Winsolu, 2009, Pengertian Kompetensi, dalam

http://my.opera.com/winsolu/blog/pen gertian-kompetensi Diakses tanggal 11 Agustus 2015 pukul 19.35 wita 